\title{
A Foreign Exchange Intervention in an Era of Restraint
}

\author{
Christopher J. Neely
}

\begin{abstract}
The Japanese yen appreciated strongly and rapidly against other major currencies in the wake of the massive March 11, 2011, Tohoku earthquake. High volatility and disorder in financial markets prompted the G-7 authorities to jointly intervene to weaken the yen. This episode resembled the two most recent G-7 coordinated interventions: the June 1998 effort to strengthen the yen and the September 2000 effort to strengthen the euro. Exchange rates reacted strongly and quickly to these three interventions, moving 3 to 4 percent in the desired direction within 30 minutes of the announcement and exhibiting lower volatility in the following days. G-7 authorities have used intervention very sparingly since 1995, yet the March 2011 policy action is a reminder that it can be used to calm markets and move the exchange rate in the desired direction. Intervention has become much less common but more successful. (JEL F31, E44, E58)
\end{abstract}

Federal Reserve Bank of St. Louis Review, September/October 2011, 93(5), pp. 303-24.

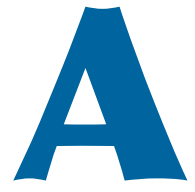

n enormous, 9.0-magnitude earthquake rocked Japan on March 11, 2011, unleashing a tsunami that swamped the Japanese coast, killing more than 15,000 people and causing hundreds of billions of dollars of property damage. ${ }^{1}$ This tremendous shock created great uncertainty in Japanese financial markets, raising concerns about future international trade and capital flows, increased expectations of government default, and reduced equity prices.

The Japanese yen (JPY) rapidly appreciated in the wake of the earthquake; from March 10 to March 17, 2011, its value rose by about 5 percent against the U.S. dollar (USD). ${ }^{2}$ The financial press cited two factors contributing to the yen's rise: (i)

1 See Hosaka (2011) and National Police Agency of Japan (2011).

2 The JPY/USD exchange rate fell from 82.98 JPY/USD at noon U.S. eastern time on March 10 to $78.74 \mathrm{JPY} / \mathrm{USD}$ at the same time on March 17, 2011. expectations that Japanese insurance companies would need to liquidate and repatriate reserves held as foreign assets and (ii) the closing of "carry trade" positions in which investors borrowed in yen to lend abroad. In the days after the earthquake, the foreign currency and equity markets became extremely volatile.

In response to these volatile market conditions, the G-7 finance ministers and central bank governors announced late on Thursday, March 17, that they would jointly intervene the next day to reduce the value of the yen. The G-7 authorities cited concerns about "excess volatility and disorderly movements" in their intervention press release. In response, the yen depreciated by 3 to 4 percent-depending on the exchange ratewithin hours.

This unusual intervention received limited media coverage. Articles in the financial press necessarily provided superficial coverage in the available space (see Pett, 2011; Vieira, 2011b;

Christopher J. Neely is an assistant vice president and economist at the Federal Reserve Bank of St. Louis. The author thanks Brett Fawley for excellent and timely research assistance.

(C) 2011, The Federal Reserve Bank of St. Louis. The views expressed in this article are those of the author(s) and do not necessarily reflect the views of the Federal Reserve System, the Board of Governors, or the regional Federal Reserve Banks. Articles may be reprinted, reproduced, published, distributed, displayed, and transmitted in their entirety if copyright notice, author name(s), and full citation are included. Abstracts, synopses, and other derivative works may be made only with prior written permission of the Federal Reserve Bank of St. Louis. 
McCormick, 2011). Sack and McNeil (2011) briefly, but very usefully, summarized the facts from the policymaker's point of view. The rarity of such episodes since 1995 and the limited press coverage will leave many readers unfamiliar with foreign exchange intervention as a policy tool.

This article describes and evaluates the success of the March 2011 action as a representative of a post-1995 policy of "rare" coordinated interventions in troubled markets. It details the macroeconomic and financial circumstances that prompted the G-7 authorities to act and describes the immediate effect on the exchange rate level and volatility. The article also compares this action with the two most recent U.S. foreign exchange interventions in June 1998 and September 2000 and puts these three episodes in the context of G-7 historical intervention experience.

Why study intervention? Exchange rate policy is important because foreign exchange markets are large and interconnected with stock and bond markets. Disorder, or lack of two-sided liquidity in foreign exchange markets, can spill over to other asset markets. ${ }^{3}$ Big swings in exchange rates can affect the balance sheets of banks and other financial firms. In addition, intervention per se can potentially offer important lessons for how asset markets function. To which aspects of intervention do exchange markets react? Through what channels does intervention work?

Furthermore, because exchange rates are important prices for international trade in goods and services, swings in such rates can affect real activity and international inflation rates. For example, an excessive rise in the value of the yen could impair Japanese tradable goods industries. And in the long run, excessive volatility could discourage international trade.

The next section defines foreign exchange intervention and summarizes some research on relevant issues. This is followed by a brief modern history of intervention and then a section describing the March 2011 intervention to restrain the yen. The circumstances and results of this intervention are compared with the two other most

3 "Two-sided liquidity" means there are substantial numbers of both active buyers and sellers in a market. recent U.S. interventions in September 2000 and June 1998.

\section{FOREIGN EXCHANGE INTERVENTION}

This section defines intervention, explains how and why it is conducted and why it might influence exchange rates, and briefly discusses research on its effectiveness.

\section{What Is Foreign Exchange Intervention?}

Foreign exchange intervention is the practice by monetary authorities or finance ministries of buying and selling foreign currency to influence exchange rates. In the United States, for example, the U.S. Treasury and the Federal Reserve generally collaborate on foreign exchange intervention decisions, and the Federal Reserve Bank of New York usually conducts such operations on behalf of both. ${ }^{4}$

Central bank purchases or sales of a foreign currency change the domestic monetary base. ${ }^{5}$ Without additional market transactions, such actions would change interest rates, exchange rates, and ultimately prices; it would simply be ordinary monetary policy conducted in the foreign exchange market instead of domestic money markets. Developed countries typically "sterilize" their foreign exchange interventions, however, which means that the central bank reverses the effects of the foreign exchange transactions on the monetary base. For example, if the New York Fed-following the instructions of the Treasury and the Federal Open Market Committee (FOMC)—sold \$500 million worth of yen (purchased dollars), the U.S. monetary base would decrease by $\$ 500$ million in the absence of steril-

\footnotetext{
4 The May 16, 1989, FOMC meeting transcript quotes Chairman Alan Greenspan as stating, "The Treasury has the legal lead on these [intervention] decisions. We discuss it with them but the ultimate decisions are theirs" (Federal Open Market Committee, 1989a, p. 7).

5 The monetary base is the domestic currency in circulation plus reserves of depository institutions held at the Federal Reserve Banks. Equivalently, it can be defined as domestic credit plus foreign exchange reserves.
} 
ization. To prevent changes in domestic interest rates and prices, the New York Fed would sterilize the intervention by buying $\$ 500$ million worth of U.S. government securities, which would increase commercial bank deposits with the Federal Reserve, thereby replacing the liquidity previously lost by the sale. To prevent yen-denominated short-term interest rates from falling, the Bank of Japan would need to conduct similar open market sales of yen-denominated securities to absorb the new liquidity and completely sterilize the original transaction. ${ }^{6}$ Almost all central banks customarily target short-term interest rates, which makes such sterilization automatic. The final net effect of such a sterilized intervention would be to decrease the supply of dollar-denominated securities relative to yen-denominated securities on the market.

\section{Why Intervene in Foreign Exchange Markets?}

The "Foreign Currency Directive" of the Federal Reserve System directs intervention to "counter disorderly market conditions," in cooperation with foreign central banks, consistent with the International Monetary Fund (IMF) Articles of Agreement; Article IV, Section 1 forbids attempts to remedy balance of payments problems by manipulating exchange rates. ${ }^{7}$ The IMF does not precisely define "disorderly market conditions"; the concept is open to interpretation. In practice, researchers such as Edison (1993) and Almekinders and Eijffinger (1996), as well as official pronouncements, support the idea that "countering disorderly market conditions"

\footnotetext{
6 In an environment in which short-term interest rates are essentially zero, changes in the monetary base do not have the usual effects on interest rates and prices. Short-term interest rates in both Japan and the United States were close to the zero lower bound at the time of the March intervention. Nevertheless, sterilization would be required if the central banks had an implicit target for bank reserves.

7 The "Foreign Currency Directive" is published annually in the minutes of the first FOMC meeting of the year. For an example, see www.federalreserve.gov/monetarypolicy/fomcminutes2011 0126.htm. The IMF's 1981 annual report, for example, states that "A member should intervene in the exchange market if necessary to counter disorderly conditions, which may be characterized inter alia by disruptive short-term movements in the exchange value of its currency" (International Monetary Fund, 1981).
}

means employing intervention to resist rapid exchange rate changes that seem contrary to perceived fundamentals. This practice is often called "leaning against the wind" or described as reducing volatility in the market.

Exchange rates are important prices that influence the time path of inflation and output. An exchange rate that is significantly away from "fundamental values" can destabilize capital and trade flows that affect inflation and output. Therefore, intervention against a recent exchange rate trend is much more likely if (i) policymakers believe that an exchange rate is "misaligned"that is, away from its fundamental value-and (ii) the recent trend is even further away from the perceived fundamental value of the exchange rate.

The idea that exchange rates can be misaligned is controversial. Fama's (1970) efficient market hypothesis suggests that asset prices always reflect fundamentals to the point where the potential excess returns do not exceed the transactions costs of acting (trading) on that information (Jensen, 1978). But it has proven very difficult to consistently link exchange rates to fundamentals in the short run. Researchers have put forward a variety of reasons-entirely consistent with rationality-to explain the persistent deviation of exchange rates from fundamentals: risk aversion, principal-agent problems, and learning and information problems. Shleifer and Vishny (1997) explore how traders are constrained by risk and principal-agent problems. Lewis (1989) and Klein and Lewis (1993) explore how learning can affect exchange rates. Whether markets are efficient or not, many policymakers believe that exchange rates can become misaligned from their fundamental values. Therefore, discussions of intervention often include the idea of "misalignment" from fundamentals or long-run equilibrium.

Although the policymaker's view of the fundamental value of the exchange is not specified and is not obvious, one can crudely calculate a long-run tendency with reference to purchasing power parity (PPP), which holds that exchange rates reflect relative price levels in the long run. The PPP-based estimate of the long-run tendency is the predicted exchange rate from a regression 
of the log of that variable on a constant, a quadratic time trend, and relative log price indexes. ${ }^{8}$

Panel A of Figure 1 shows the JPY/USD exchange rate and its estimated long-run trend. Panel B shows the time series of U.S. interventions in the JPY/USD exchange rate; USD purchases (sales) are positive (negative). Panel C displays a scatterplot of the interventions versus the deviations of the exchange rate from its trend. The negative relation in panel C clearly shows that U.S. authorities tend to buy dollars when the price of dollars in terms of JPY is below its longrun tendency and sell dollars when the JPY price of dollars is above its long-run tendency. Contingency analysis confirms that most official U.S. intervention in the deutsche mark (DEM) or euro (EUR) and JPY markets is consistent with pushing the exchange rate toward long-run equilibrium. For example, about 61 percent of U.S. interventions are in either the top-left or lower-right quadrant in panel C, indicating a USD sale when the dollar is strong or a USD purchase when the dollar is weak, respectively. Panel C displays the two most recent U.S. interventions in the JPY marketon June 17, 1998, and March 18, 2011-as solid blue and black markers, respectively. These interventions are the two largest JPY interventions, but they are consistent with the tendency of U.S. authorities to buy (sell) dollars when the dollar is weak (strong) relative to its long-run trend. ${ }^{9}$

\section{How Might Foreign Exchange Intervention Work?}

Because sterilized intervention affects neither prices nor interest rates, it does not influence the exchange rate directly through these usual mechanisms. But official intervention might affect the foreign exchange market indirectly through the portfolio balance channel, the signaling channel, and/or the coordination channel.

The portfolio balance theory recognizes that sterilized intervention changes the relative sup-

8 The quadratic time trend, which is highly statistically significant, permits a time varying Balassa-Samuelson effect, which denotes the tendency for differential productivity growth to affect real (i.e., inflation-adjusted) exchange rates.

${ }^{9}$ One might expect intervention sizes to grow over time with the size of financial markets. plies of bonds denominated in different currencies. If bonds from different countries are imperfect substitutes (as seems likely) and investors have only a limited appetite for the bonds from a particular country at a given rate of return, then the relative rate of return on, say, Japanese versus U.S. bonds, must depend on the relative quantities of those types of bonds. In the example in which the Fed purchases dollars/sells yen, the intervention increases the quantity of yen-denominated bonds relative to dollar-denominated bonds. Such an increase in the relative quantity of yendenominated assets means that international investors will require a higher return on these bonds. An immediate depreciation of the yen creates a higher expected return on yendenominated assets without changing the longrun value of the JPY/USD. Researchers are skeptical of the portfolio balance channel's importance because interventions are typically much, much too small to significantly change the relative quantities of bonds.

The signaling channel suggests that official intervention communicates (signals) information about future monetary policy. The literature on intervention has not been kind to the signaling hypothesis. Lewis (1995) and Kaminsky and Lewis (1996) found that intervention generated perverse impacts on monetary policy in their sample. Fatum and Hutchison (1999) found that intervention had no impact on federal funds futures rates. Aside from the problem that intervention seemingly does not affect expected monetary policy, the signaling story seems implausible because monetary policy and exchange rate policy are often in the hands of different institutions. If the U.S. Treasury has primary responsibility for the value of the USD, for example, then how can intervention signal anything about monetary policy, which is in the hands of the FOMC?

The coordination channel, which suggests that intervention might be important in coordinating the expectations of market participants, has received more attention recently. Sarno and Taylor (2001), Taylor (2005), and Reitz and Taylor (2008) have emphasized its potential importance in communicating that authorities consider that the exchange rate is deviating substantially from 


\section{Figure 1}

\section{The JPY/USD Exchange Rate and U.S. Intervention}

A.

JPY/USD

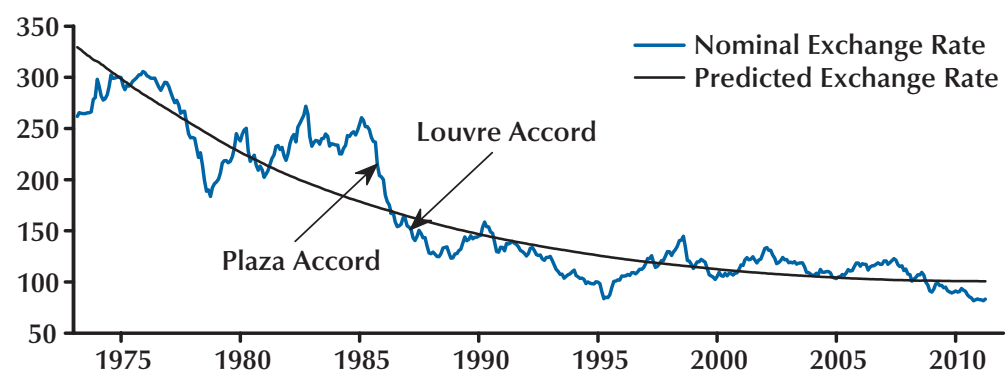

B.

\$ Millions (USD)

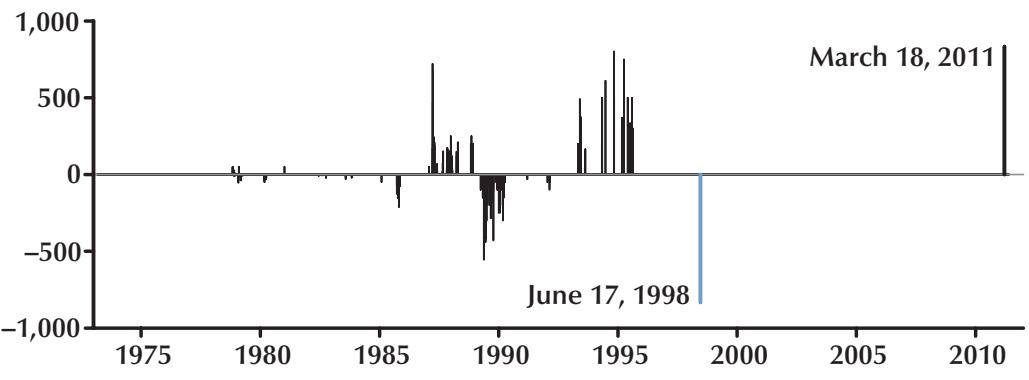

C.

Percent Deviation in Exchange Rate from Trend

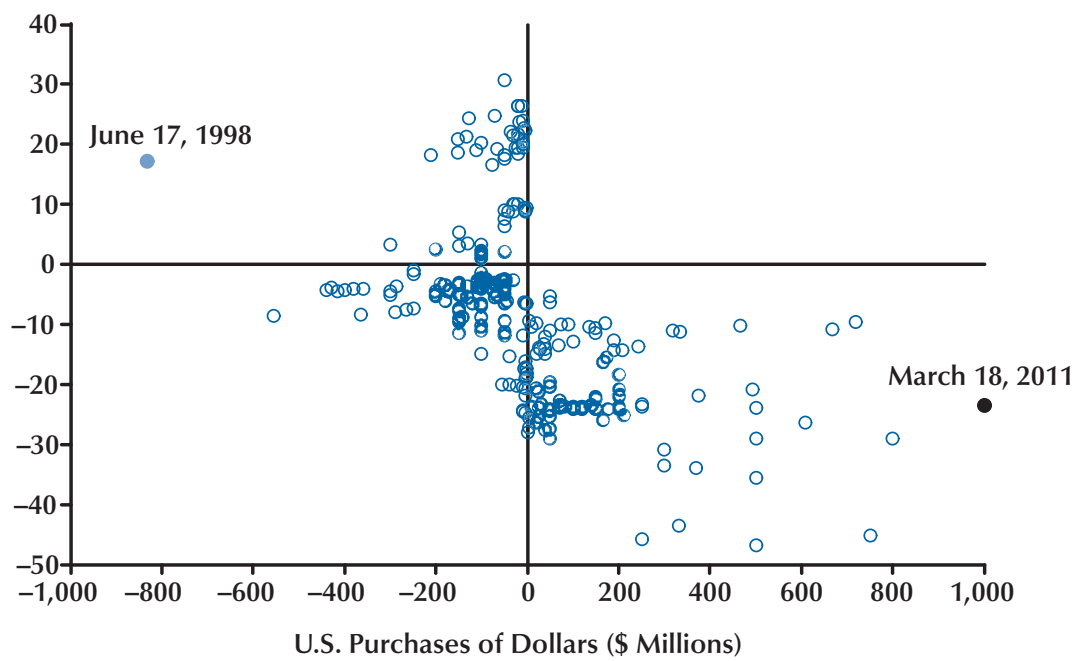

NOTE: Panel A shows the JPY/USD exchange rate and a long-run equilibrium fundamental estimated from relative prices and a quadratic time trend. Panel $B$ shows the U.S. foreign exchange intervention (millions of USD purchased) over the same sample. Panel C is a scatterplot of nonzero U.S. intervention versus the deviation from the estimated trend. The June 17, 1998, and the March 18, 2011, interventions are labeled in panels B and C. 
its long-run value. During such periods, it can be extremely risky for individual investors to invest much capital in hopes of a return to long-run equilibrium. As Keynes noted, "Markets can remain irrational a lot longer than you and I can remain solvent" (see Shilling, 1993, p. 236). Nevertheless, a foreign exchange intervention can coordinate the expectations of market participants and lead investors to drive the exchange rate back toward its long-run equilibrium.

\section{Does Intervention Work?}

There is no strong consensus on the effectiveness of sterilized intervention in floating markets. ${ }^{10}$ Sarno and Taylor (2001) report mixed evidence in their thorough survey of the literature. More recently, Bordo, Humpage, and Schwartz (2010) report on the mostly limited success of U.S. intervention efforts in the 1970s. Neely (2005) argues that the problem in finding effects of intervention is sorting out the simultaneity in the conditions under which intervention is conducted versus the effects of that intervention. Studies that consider this problem more seriously-that is, Kearns and Rigobon (2005) and Neely (2006) find that sterilized intervention does have desired effects. Similarly, high-frequency studies, such as Fischer and Zurlinden (1999) and Payne and Vitale (2003), which tend to be less afflicted by simultaneity problems, have also found intervention to be effective. Finally, Neely (2008) surveys monetary authorities and finds that policymakers experienced in floating exchange rate markets overwhelmingly believe that intervention works in floating exchange rates.

In any case, developed countries have increasingly avoided the practice of foreign exchange intervention. Truman (2003) eloquently describes a typical view among recent policymakers:

\footnotetext{
${ }^{10}$ It is important to distinguish intervention to defend fixed exchange rates, such as that conducted by the Bank of England in 1992 or the Banco de Mexico in 1994, from intervention in floating rate markets. Research is fairly clear that sterilized intervention cannot replace the use of fundamentals (i.e., monetary policy) in defending fixed exchange rates. Sterilized intervention in floating exchange rate markets is a different story, however. Unlike monetary authorities defending a fixed peg, exchange rate authorities can pick and choose the time and manner of intervention in floating rate markets.
}

The evidence on the short-run effectiveness of exchange market intervention is sufficient in my view to support the judicious use of intervention by the United States as a supplementary policy instrument as long as it generally is used in a manner consistent with other economic policies; however, that same evidence falls substantially short of demonstrating that intervention is a separate policy instrument that can be used to manage exchange rates with any lasting effect.

What harm is there in using an instrument that may or may not be at all effective but at least is associated about half the time with success? The harm lies in the potential for collateral damage by, for example, distracting the authorities from correcting fundamental economic policies, sending incorrect signals about those policies, or potentially moving exchange rates in directions inconsistent with those policies. These considerations suggest some of the limits on intervention as a policy tool; it may not be effective and it may not be a benign instrument (p. 248).

In other words, Truman views intervention as (perhaps) a useful tool in rare situations in which it can be used to shock or communicate with markets, but he also thinks that it cannot reliably be used to move exchange rates wherever the policymaker likes. In addition, its regular use poses the danger that policymakers might view it as a routine substitute for changes in fundamental policies. ${ }^{11}$

\section{A BRIEF HISTORY OF G-7 FOREIGN EXCHANGE INTERVENTION}

The coordinated intervention of March 18, 2011, is one episode in an implicit policy regimeperhaps 15 years old-that recognizes that intervention can be a useful policy tool in rare and

\footnotetext{
${ }^{11}$ Truman was formerly the director of the Division of International Finance at the Board of Governors, so he is very familiar with the practice of intervention by the United States in the 1980s and 1990s. One might note that although the policymakers surveyed by Neely (2008) seemed to disagree with Truman's assessments of the effectiveness of intervention, they did share his concern that sterilized intervention might be used to substitute for other policies.
} 
extreme circumstances. Prior to 1996, however, G-7 authorities intervened much more often. This section discusses the history of intervention in major currencies to explain the evolution of policy to its current state.

\section{Pre-1973 Exchange Rate Policies}

Governments have conducted policies to influence exchange rates for a very long time. Successful British, U.S., and French exchange transactions in 1927-31 to support the British pound, Austrian schilling, and German mark directly anticipated modern intervention operations (Bordo, Humpage, and Schwartz, 2007). ${ }^{12}$ U.S. spot foreign exchange interventions to stabilize financial markets in the wake of disruptions such as the Kennedy assassination and the Cuban Missile Crisis (Bordo, Humpage, and Schwartz, 2007) presaged interventions to counter "disorderly markets" in the 1996-2011 period.

\section{Intervention in Floating Exchange Rates (1973-1995)}

After the Bretton Woods system of pegged exchange rates collapsed in March 1973, G-7 currencies floated against the dollar. Floating exchange rates tended to be more volatile than had been anticipated and neither authorities nor foreign exchange traders had much experience with them. Perhaps as a consequence, G-7 authorities tended to second-guess market movements by intervening frequently from 1973 to 1981.

Initially, the Reagan administration did not view intervention as a useful tool and intervened little from 1981 to 1985 . Other countries, particularly West Germany, did intervene to attempt to stem the dollar's strong appreciation during that period. The very strong dollar and the resultant international imbalances eventually prompted the governments of France, West Germany, Japan, the United States, and the United Kingdom to sign the Plaza Accord on September 22, 1985, to cooperate to intervene to depreciate the dollar

\footnotetext{
${ }^{12}$ Suspicious of competitive devaluations by transactions from the British Exchange Equalization Account, the United States established the Exchange Stabilization Fund in 1934 to "stabilize" the foreign exchange value of the dollar.
}

(see Figure 1). Perhaps partly as a consequence, the DEM/USD exchange rate fell 3.75 percent from September 20 to September 23 and about 37 percent between September 20, 1985, and February 2, 1987.

This large decline in the dollar's value prompted the February 22, 1987, Louvre Accord, in which Canada, France, West Germany, Japan, the United Kingdom, and the United States pledged to cooperate to stem the dollar's decline (see Figure 1). Shortly afterward, these partners intervened to purchase dollars and the dollar remained stable only for some weeks. ${ }^{13}$

Growing disenchantment with intervention led members of the FOMC-Governors Angell and LaWare and President Hoskins-to criticize U.S. intervention practices in 1989. ${ }^{14}$ Kaminsky and Lewis (1996) report that, by the end of 1989, the New York Fed conducted intervention exclusively for the Treasury and no longer retained half of the intervention operations on its own books. This was very unusual as the Treasury and Federal Reserve have typically cooperated closely on such activities. It signaled, however, growing skepticism about the efficacy of intervention.

\section{The Post-Intervention Era}

By the mid-1990s, authorities of developed countries had grown skeptical about the efficacy of foreign exchange intervention operations. With only rare exceptions, the Bank of England stopped intervening after February 1993 and the Bundesbank and U.S. authorities likewise ceased the practice after 1995. ${ }^{15}$ The Bank of Canada stopped intervening in 1998. The European

\footnotetext{
${ }^{13}$ Dominguez (1990) reviews U.S. intervention policies from 1985 through 1987.

${ }^{14}$ At the May 16, 1989, FOMC meeting, Governor Angell and President Hoskins expressed reservations about the effectiveness of intervention and suggested that the G-7 partners should change other [monetary and/or fiscal] policies. Governor LaWare dissented on a motion to authorize up to $\$ 15$ billion in foreign currency balances for the Federal Reserve System (FOMC, 1989a). Criticism continued at the August 22, 1989, FOMC meeting; Governor Angell cited concerns about the consistency of a depreciating dollar with the desired goal of price stability (FOMC, 1989b).

${ }^{15}$ The Swiss National Bank also stopped frequent intervention in 1995. In contrast to these trends, the Reserve Bank of Australia has continued to intervene, mostly purchasing foreign currency over the past 10 years (see Reserve Bank of Australia).
} 


\section{Figure 2}

\section{Timeline of G-7 (and Swiss) Intervention Practices}

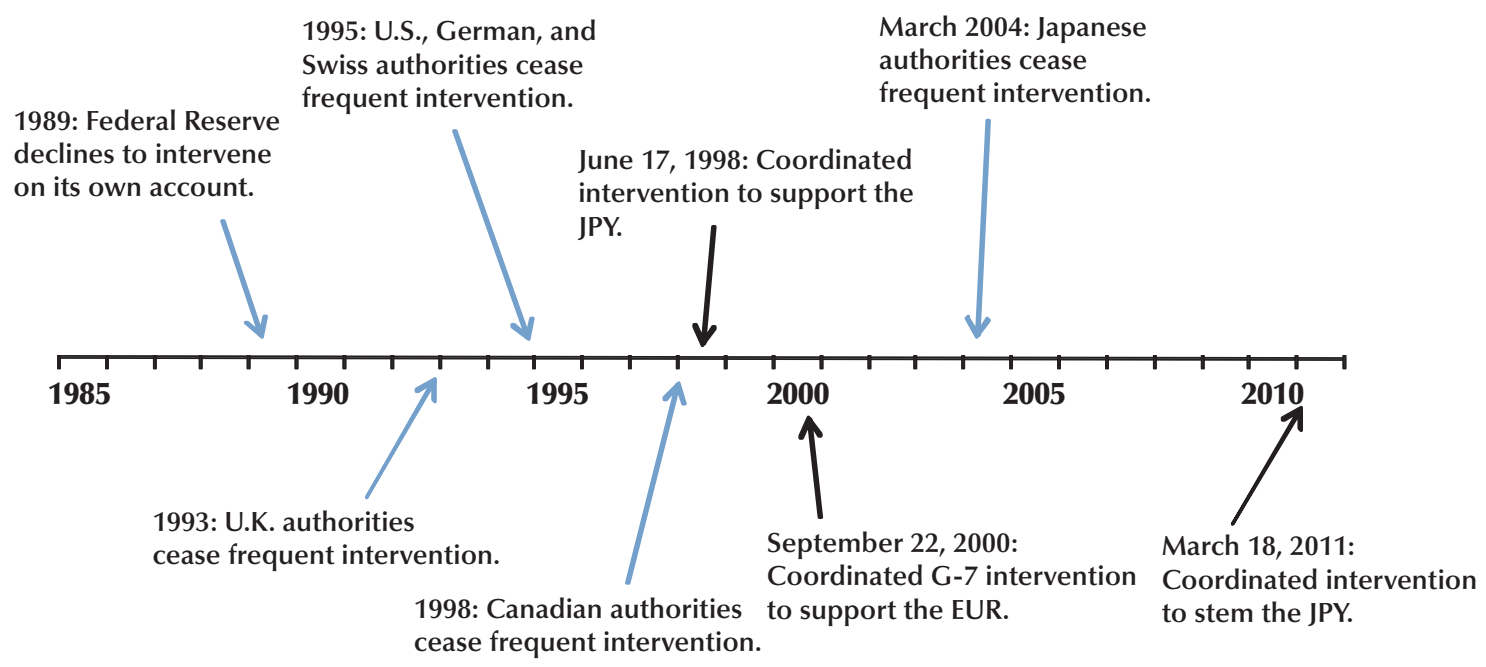

NOTE: Timeline for G-7 (and Swiss) intervention practices after 1985.

Central Bank (ECB) has intervened only rarely since its inception in 1999. ${ }^{16}$ These authorities have made three exceptions to this aversion to intervention: a June 1998 effort to support the JPY, a September 2000 attempt to support the EUR, and the March 2011 collaboration to restrain the JPY. Figure 2 illustrates the timeline of these actions and the three post-1995 major coordinated interventions (black arrows).

\section{THE GREAT INTERVENTION OF 2011}

\section{The Earthquake and Its Aftermath}

The economic devastation created by the March 11 earthquake was record-breaking, with hundreds of billions of dollars in property damage. ${ }^{17}$ As might be expected in such a circumstance, Japanese markets were extremely volatile.

\footnotetext{
${ }^{16}$ Japan, traditionally very mindful of the level of the yen, continued to intervene fairly frequently until March 2004, since which it has intervened only twice.

${ }^{17}$ See Hosaka (2011) and National Police Agency of Japan (2011).
}

The great uncertainty induced in Japanese financial markets increased expectations of government default and reduced equity prices. Figure 3 shows that a major Japanese equity index, the Nikkei 225, fell by about 18 percent from March 10 to March 15 and its annualized volatility skyrocketed to almost 90 percent, more than three times normal levels. Figure 4 illustrates that Japanese interest rates were already very low and did not move much.

Sound fundamental reasons existed for such financial turmoil: Figure 5 shows that the index of Japanese industrial production unexpectedly fell precipitously from February to March, from over 100 to less than 82. Simultaneously, as a result of the destruction of production facilities and the need for emergency aid, the Japanese trade balance declined from a $\$ 5$ billion surplus in February to approximately zero in March and a $\$ 6$ billion deficit in April (Figure 6). Reduced exports explained almost the entire decline.

The financial press reported that two considerations dominated foreign exchange market reaction to the earthquake. First, participants expected that Japanese insurance companies 


\section{Figure 3}

\section{The Nikkei 225 After the Japanese Earthquake}

A.

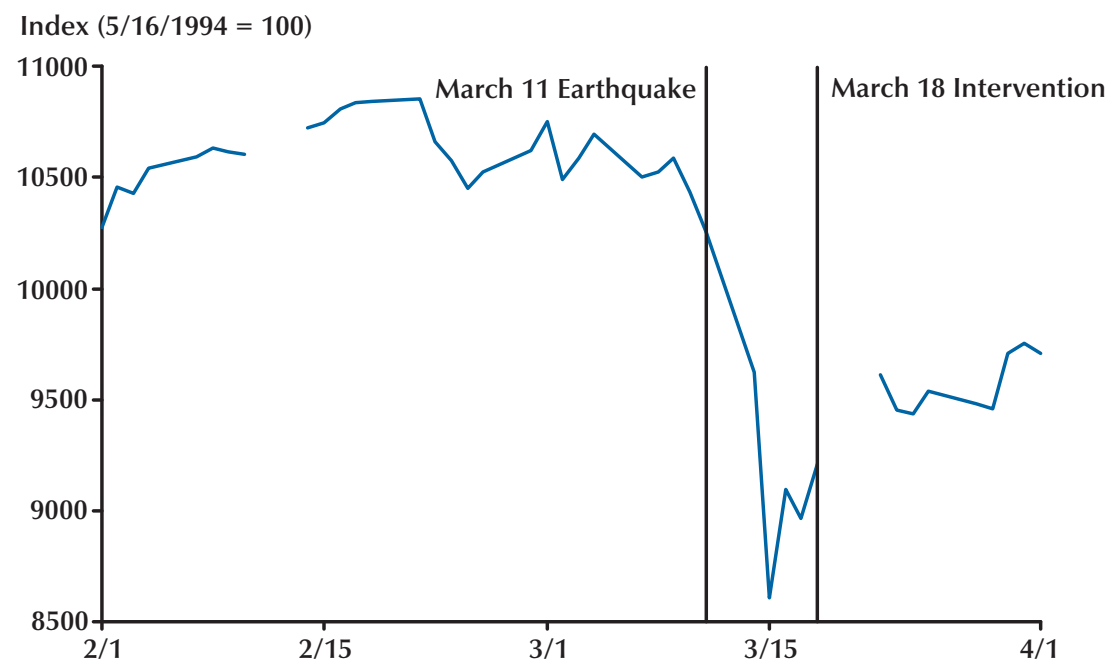

B.

Realized 5-Minute Volatility (annualized)

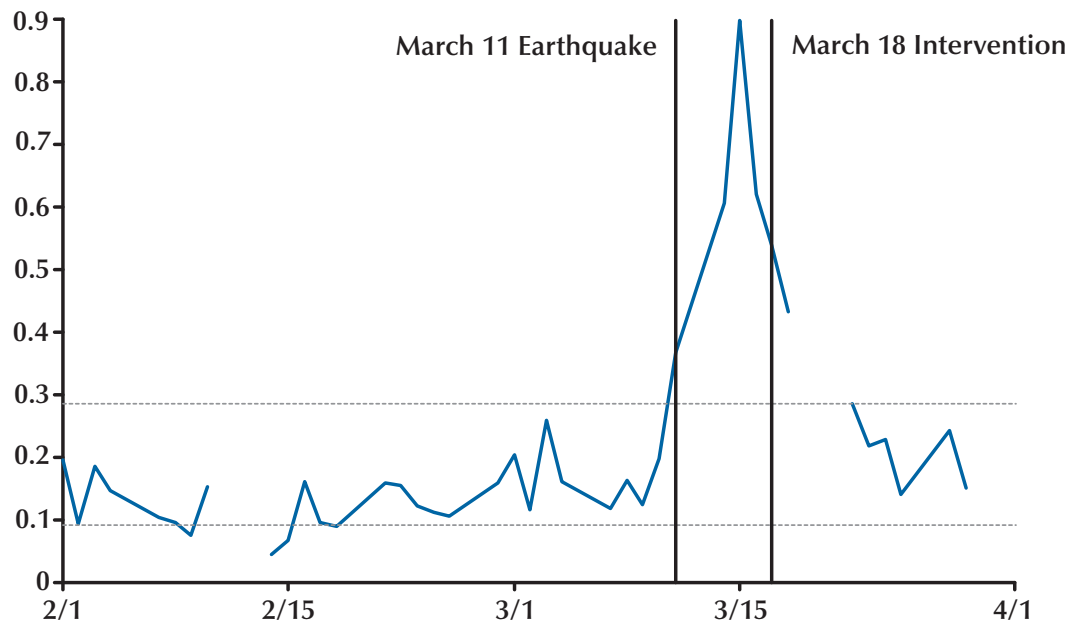

NOTE: Panel A shows the Nikkei 225 index from February 1, 2011, through March 31, 2011; panel B shows realized volatility for the same period computed from 5-minute squared returns. The vertical lines denote the March 11 earthquake and the March 18 intervention. The horizontal lines in panel B show the 10th and 90th percentiles of volatility for the Nikkei 225 index from July 1,2003 , to March 31, 2011. 
Figure 4

Japanese Interest Rates After the Earthquake

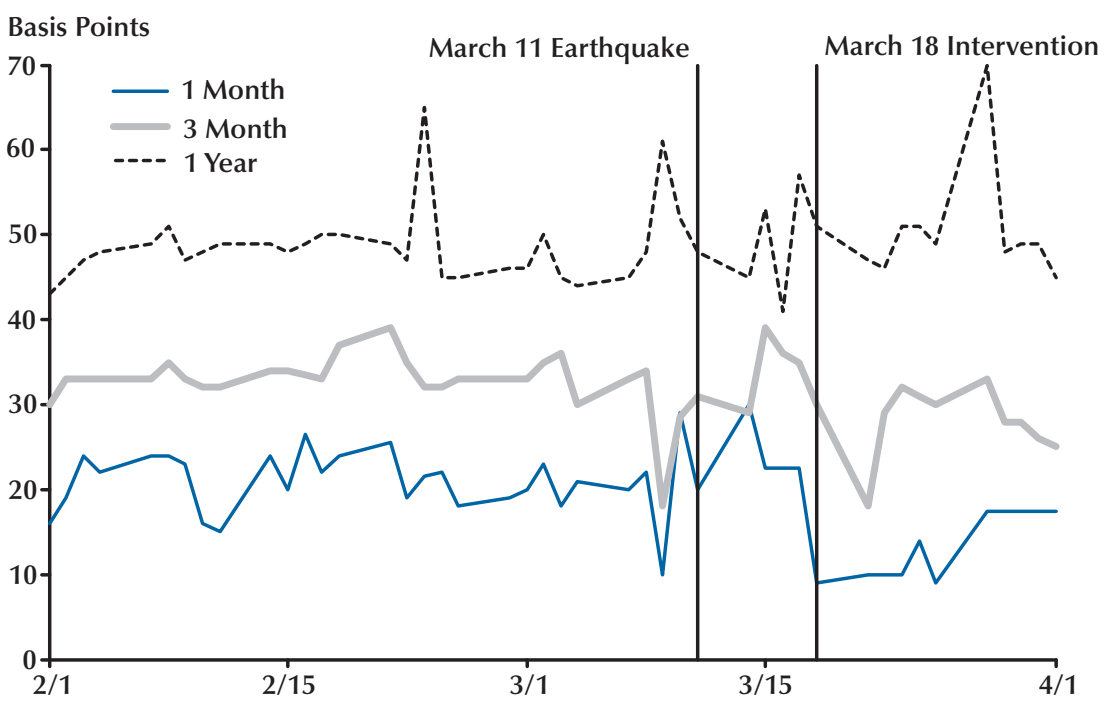

NOTE: The figure shows 1-month, 3-month, and 1-year Japanese interest rates from February 1, 2011, through March 31, 2011. The vertical lines denote the March 11 earthquake and the March 18 G-7 intervention.

\section{Figure 5}

\section{Japanese Industrial Production}

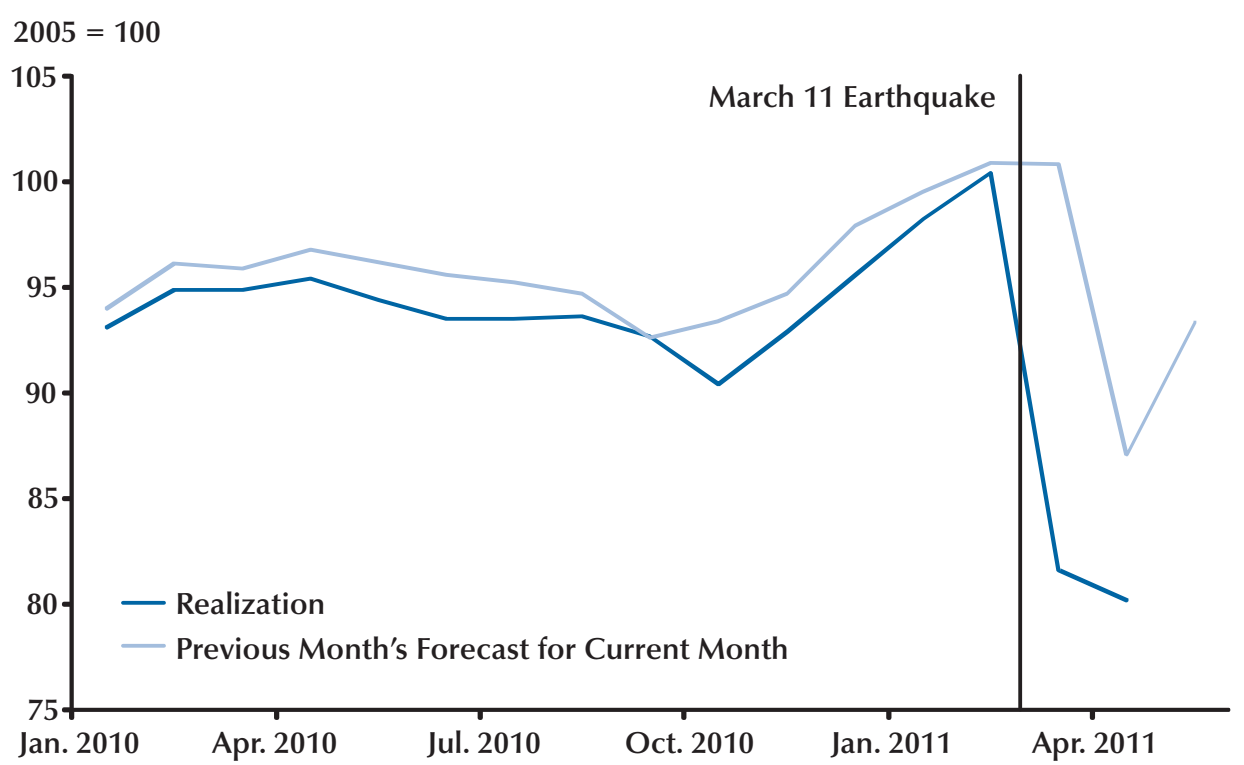

NOTE: The dark blue line shows Japanese industrial production; its one-month-ahead forecast is shown by the light blue line. The vertical line denotes the break between the February and March observations. 


\section{Figure 6}

\section{Japanese Trade Balance}

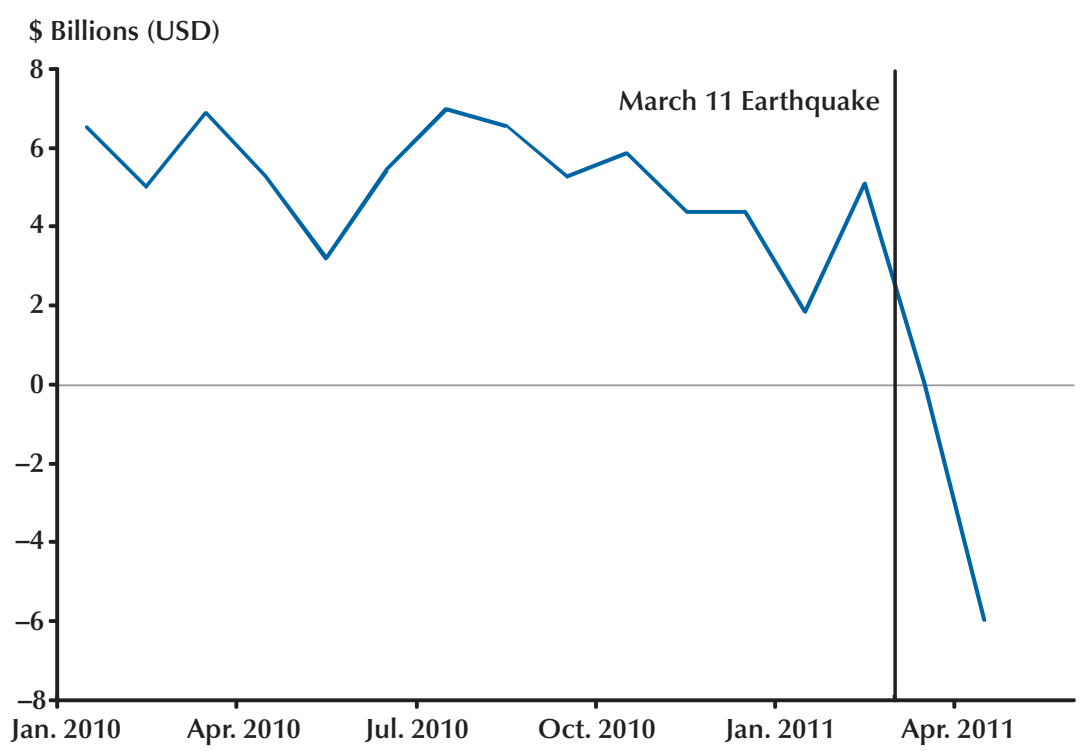

NOTE: The vertical line denotes the break between February and March observations.

would need to liquidate and repatriate reserves held as foreign assets. Second, Japanese investors in the carry trade-in which one borrows in low interest rate countries, such as Japan, to invest in high interest rate countries-chose to close out their Japanese borrowing in anticipation of the need for the funds. Both factors tended to strengthen the yen. The yen rapidly appreciated by 5.1 percent against the USD after the earthquake: from $82.98 \mathrm{JPY} / \mathrm{USD}$ at noon U.S. eastern time on March 10 to 78.74 JPY/USD on March 17, 2011

(Figure 7). Given an 18 percent decline in industrial production within one month and plunging exports, this rapid rise in the yen's value seriously threatened the health of Japanese tradable industries.

At the same time, JPY/USD volatility rose to unusually high levels after the earthquake. Figure 8 shows that (i) realized volatility reached an annualized level of more than 50 percent on March 16, which was three times the 90th percentile of its distribution, and (ii) 1-week implied volatility reached 22 percent on March $17 .{ }^{18}$
Figure 9 shows that JPY/USD trading volume grew rapidly after the March 11 quake, about tripling by March 17. G-7 officials were reportedly concerned about the effect of this turmoil on financial markets already under stress from the European debt crisis and turbulence in the Middle East. Although the earthquake clearly changed fundamentals and the appropriate path of the yen's value, Japanese officials did not think that the fundamentals justified the observed price movements.

\section{The Intervention to Stem the Yen's Rise}

Despite this evidence of "disorderly markets," financial press reports indicated that the G-7 members were unlikely to agree to intervene. ${ }^{19}$

\footnotetext{
${ }^{18}$ Researchers have often measured volatility with either implied volatility or realized volatility. Implied volatility is an estimate of future volatility derived from option prices; realized volatility is the annualized square root of the sum of high-frequency squared returns within a day (Andersen and Bollerslev, 1998).

19 "Yet one G7 official told Reuters that, instead, policymakers from the world's top industrialized economies are more likely to offer solidarity to Japan, the world's No. 3 economy-as opposed to agree to market intervention" (Vieira, 2011a).
} 
Figure 7

\section{JPY Exchange Rates}

A.

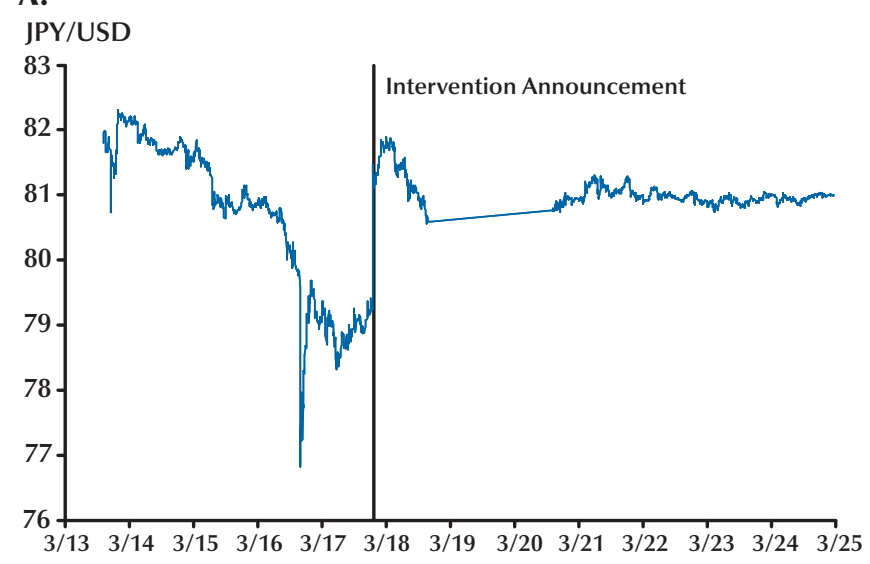

B.

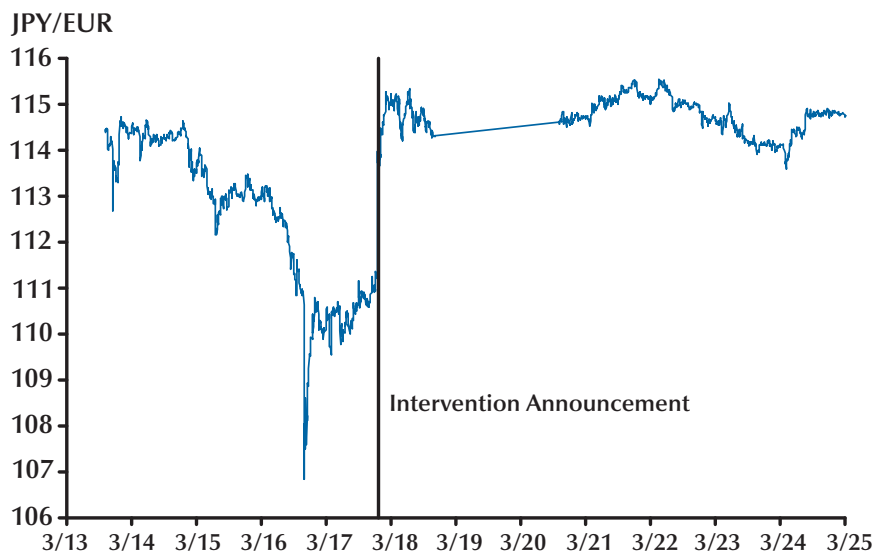

C.

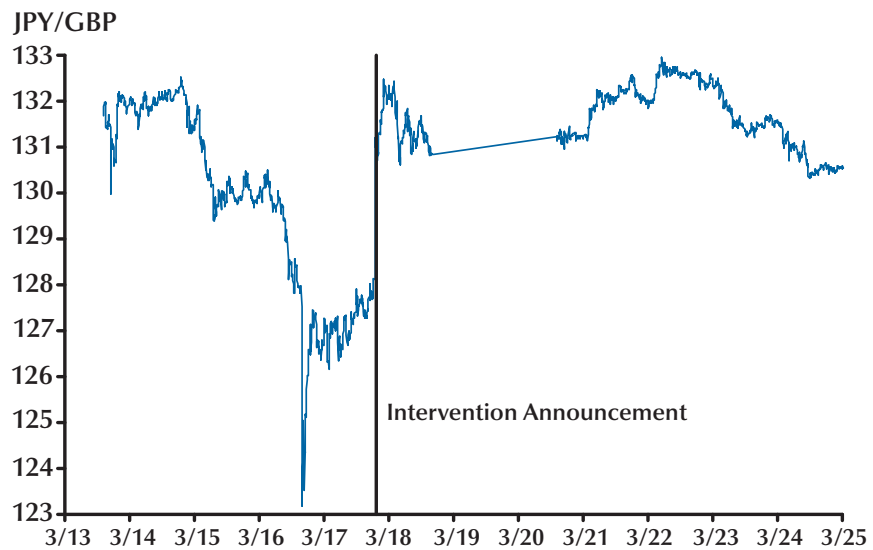

NOTE: The three panels show the evolution of the JPY/USD (panel A), JPY/EUR (panel B), and JPY/GBP (panel C) exchange rates from March 13, 2011, to March 24, 2011. The vertical lines denote the date/time of the announcement of the coordinated foreign exchange intervention. 


\section{Figure 8}

\section{JPY/USD Realized and Implied Volatility}

A.

Realized 5-Minute Volatility (annualized)

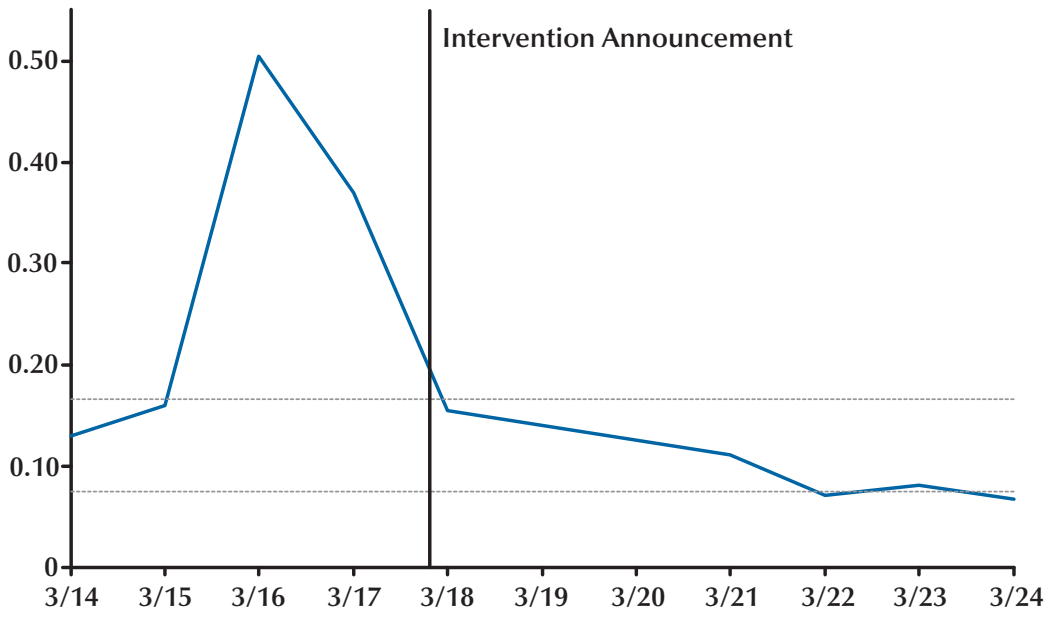

B.

Implied Volatility (annualized)

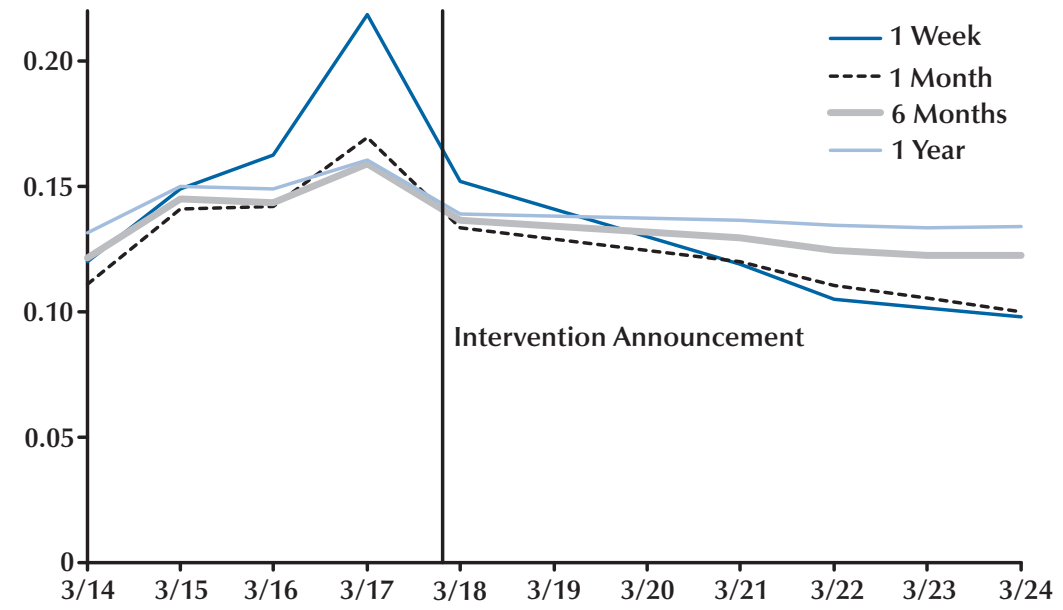

NOTE: Panel A shows the annualized realized volatility, computed from 5-minute squared returns, for the JPY/USD market from March 14 to March 24, 2011. The horizontal lines show the 10th and 90th percentiles of volatility for the JPY/USD over the March 26, 1998-March 31, 2011, period. Panel B shows option-implied volatility over four horizons for the same market during the same period in March 2011. 
Figure 9

\section{Daily JPY/USD Turnover in Tokyo Foreign Exchange Markets (March 2011)}

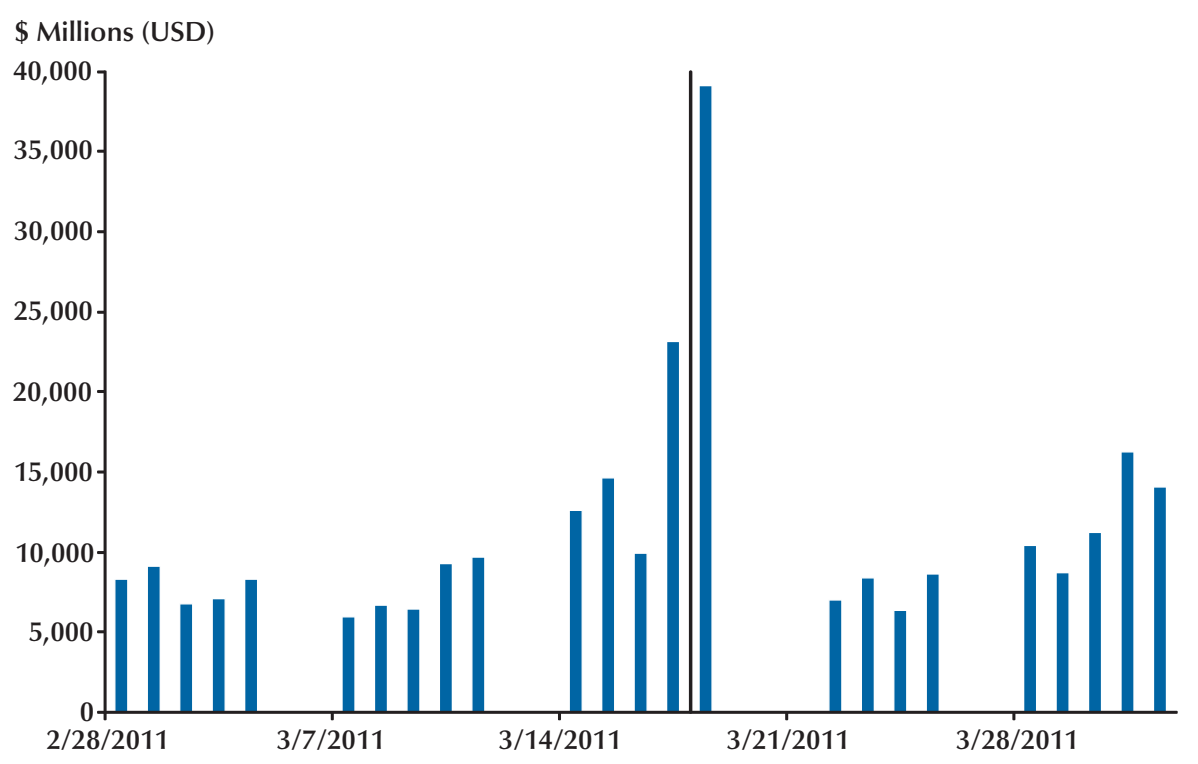

NOTE: The graph illustrates the daily turnover in Tokyo foreign exchange markets during March 2011. The vertical line denotes the intervention announcement on the morning of March 18, Tokyo time.

Nevertheless, the G-7 finance ministers and central bank governors held a conference call on the evening of Thursday, March 17 (Friday morning in Tokyo) and decided to conduct a coordinated intervention to weaken the JPY. The G-7 issued a press release containing the following text:

In response to recent movements in the exchange rate of the yen associated with the tragic events in Japan, and at the request of the Japanese authorities, the authorities of the United States, the United Kingdom, Canada, and the European Central Bank will join with Japan, on 18 March 2011, in concerted intervention in exchange markets. As we have long stated, excess volatility and disorderly movements in exchange rates have adverse implications for economic and financial stability. We will monitor exchange markets closely and will cooperate as appropriate (G-7, 2011).

Figure 7 shows that the yen reacted immediately to the intervention announcement, surging almost 4 percent within the hour against the USD, EUR, and GBP. Markets responded to the announcement of the intention to intervene rather than to the actual transactions, because efficient markets require a rapid reaction to publicly available information to preclude obvious risk-adjusted profit opportunities. One might also note in Figure 7 that the yen weakened modestly in the 18 hours preceding the announcement, perhaps in anticipation of G-7 action. Similarly, Figure 8 shows that both realized and implied volatilityboth at very high levels before the intervention announcement-fell significantly the next day and even more so by Monday, March 21. Realized volatility, for example, declined below the 90th percentile of its distribution. Foreign exchange turnover declined to normal levels in the week following the intervention (see Figure 9). At the same time, Figure 3 shows that the Nikkei 225 rose about 5 percent over the weekend after the intervention and volatility declined by the end of the following week to normal levels, suggesting that financial markets viewed the intervention as favorable to Japanese corporate profits (and growth). 


\section{Are These Results Consistent with Literature Predictions?}

Are the results of the March 18, 2011, intervention consistent with the best estimates in the literature on the impact of intervention? Several facts complicate such comparisons. First, the literature has typically assumed, for simplicity, that intervention has a linear impact in proportion to its size. Moreover, the fact that the clearest market reaction was to the intervention announcement, not to the actual intervention transactions, suggests that the intervention amount might be almost irrelevant. On the other hand, if the size of intervention is important, it might be the size relative to market turnover. Most studies of intervention have used data from the mid-1980s to the mid1990s, but turnover in the foreign exchange market has doubled or tripled since 1995. Second, factors such as the degree of international coordination might be important but are difficult to quantify. Central bankers responding to the survey in Neely (2008), for example, tend to agree that large and coordinated interventions are more effective. It is difficult to cleanly compare the present results with those of the intervention literature because an intervention's impact might vary over time and with the nature of the exchange rate market.

Nevertheless, assuming that the intervention amount actually mattered and that markets anticipated the amounts fairly well, one can compare the observed changes in the wake of the announcement with predictions from the literature. Dominguez (2003), who studied G-3 intervention at an intraday frequency, found that a $\$ 100$ million U.S. intervention in the DEM market had a maximal impact of almost 3 basis points. Using daily data, Kearns and Rigobon (2005) found that a \$100 million Bank of Japan intervention had a 20-basis-point impact in the JPY/USD market. Neely (2006) found that a \$100 million USD purchase caused a 5- to 6-basis-point USD appreciation in either the DEM/USD or JPY/USD markets. Extrapolating from these estimates, one might predict that a $\$ 10$ billion intervention might cause a 3 to 20 percent change.

How big was the 2011 intervention? The Japanese, U.S., Canadian, and U.K. authorities announced expenditures of about $\$ 8.7$ billion, \$1 billion, \$124 million, and \$125 million, respectively, in the joint intervention. ECB authorities have not publicly released its intervention amounts, but one might interpolate from changes in the net ECB foreign currency position that it was in the neighborhood of $\$ 420$ million. Therefore, the total intervention amount probably was about $\$ 10.4$ billion. $^{20}$ The actual change in the exchange rate-about 4 percent-is roughly consistent with the predictions of 3.12 and 5 to 6 percent implied by Dominguez (2003) and Neely (2006), respectively, but it is considerably smaller than the 20-percentage-point estimate implied by Kearns and Rigobon (2005).

There is also a large literature that comes to mixed conclusions about the effect of intervention on volatility and higher moments (see Campa and Chang, 1998; Dominguez, 2003; Beine et al., 2007). The difficulty in separately identifying the simultaneous effects of intervention and volatility on each other might explain these mixed results. That is, intervention responds to volatility, so these variables will be positively correlated. Volatility does tend to decline in the hours and days following intervention, but it is difficult to ascertain whether the decline is the result of intervention or simply the natural tendency of very volatile markets to return to normal volatility levels over time.

Still, there is a remarkable drop in both realized (current) and implied (forward-looking) volatility associated with the March 18 intervention (see Figure 8). The fact that the short-horizon implied volatility dropped much further after the intervention suggests that the intervention did calm markets in a somewhat unexpected manner.

\section{Comparison with June 1998}

The United States has intervened in foreign exchange markets on only two other occasions since 1995: June 17, 1998, and September 22, 2000. How does the March 2011 intervention

\footnotetext{
20 The Japanese, U.S., Canadian, U.K., and ECB intervention data are from the following sources, respectively: Ministry of Finance Japan (2011), Sack and McNeil (2011), Department of Finance Canada (2011), HM Treasury (2011), and European Central Bank (2011).
} 
compare with those events in terms of motivation and exchange market response?

The June 1998 intervention also followed a financial crisis, the 1997 Asian exchange rate crisis in which international capital fled many developing Asian countries, such as Thailand and South Korea. In early June 1998, the main macroeconomic concern was that the yen was unusually weak and weakening further (see Figure 1), which made goods and services from other Asian countries less competitive with Japanese goods and services and harmed those countries' recoveries. Policymakers probably feared that a falling yen might cause China to devalue the renminbi (RMB), possibly sparking competitive devaluations, inflation, and instability throughout the region.

Financial markets were also in turmoil in June 1998. Panel A in Figure 10 shows that realized volatility was high in the days preceding the June 17 intervention, peaking at almost 40 percent per annum, well above the 90th percentile for its distribution. Panel B shows that the yen weakened by about 3 percent from June 11 to June 15.

The yen did strengthen modestly on June 15 and 16 in response to press reports that U.S. and Japanese officials had discussed intervention. Japanese officials had been pressing their U.S. counterparts for cooperation to raise the value of the yen. Prime Minister Hashimoto's promises of economic reform reportedly won over U.S. Treasury Secretary Rubin and President Clinton, who had been pressing for changes in Japanese policy (Dow Jones, 1998).

Rumors of strong U.S. intervention began to leak out at 8 a.m. (U.S. eastern time) on June 17 and an official statement from the U.S. Treasury confirmed the action at 8:16 a.m. (Hewett, 1998). The yen then strengthened by about 3.5 percent within the hour and realized volatility declined to normal levels by the following Monday. The intervention had its desired immediate impact.

\section{Comparison with September 2000}

The recent entry of a major new central bank to currency markets set the stage for the September 22, 2000, intervention. On January 1, 1999, the ECB began conducting a common mon- etary policy with a new currency, the euro, for the 11 original nations of the European Monetary Union (EMU). From its inception, the euro tended to depreciate against the dollar, falling from about 1.18 USD/EUR on the inception date to less than 0.85 USD/EUR in September 2000. Doubts about the policies of the new central bank probably contributed to this weakness. At the same time, the U.S. economy was slowing-it would officially enter a recession in March 2001-and the strong dollar/weak euro was perceived as detrimental to U.S. exporters. In addition, the Japanese feared that an overly strong yen would price Japanese exports out of the European markets (Holland, 2000). Against this backdrop, the ECB, the United States, and Japan decided to intervene to support the euro on September 22, 2000. The timing of the action was surprising; it occurred the day before a meeting of G-7 finance ministers and central bank governors.

Figure 11 shows a pattern consistent with that of the other interventions: There was a somewhat modest strengthening of the euro in the 24 hours preceding the intervention and a large (4 percent) move at the time of the intervention with perhaps a 1 percent retrenchment over the following hours. As with the other intervention episodes, volatility declined to less than the 90th percentile of its distribution within a couple of days.

\section{A Long-Term Effect?}

A perennial question in research on foreign exchange intervention is the duration of its effects: Are the effects permanent? Unfortunately, this question cannot be answered. The nature of asset prices makes it impossible to prove that intervention has a prolonged or permanent effect, no matter what effect that intervention has. To illustrate this point, suppose that (i) the recent G-7 intervention increased the JPY/USD exchange rate by 4 percent and (ii) this effect was "permanent" in the sense that the JPY/USD rate would forever be 4 percent higher than it would have been without the intervention. Suppose, too, that JPY/USD returns have a normal distribution and an annual standard deviation (SD) of 12 percent per annum, which translates into a monthly SD of about 3.5 percent. That means that within 1 month, there 


\section{Figure 10}

\section{JPY/USD Market Behavior Near the June 17, 1998, Intervention}

A.

Realized 5-Minute Volatility (annualized)

JPY/USD

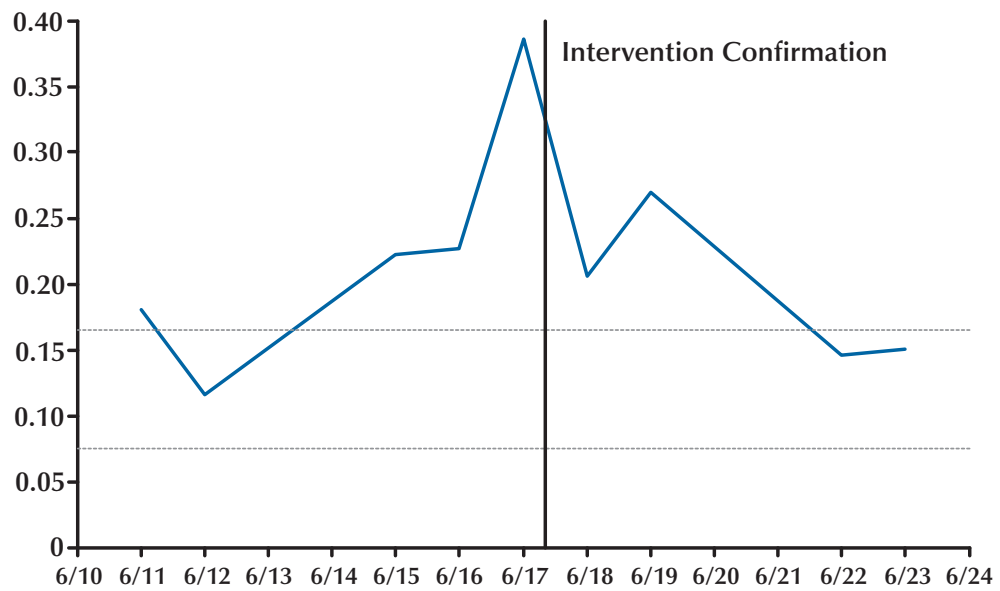

B.

JPY/USD

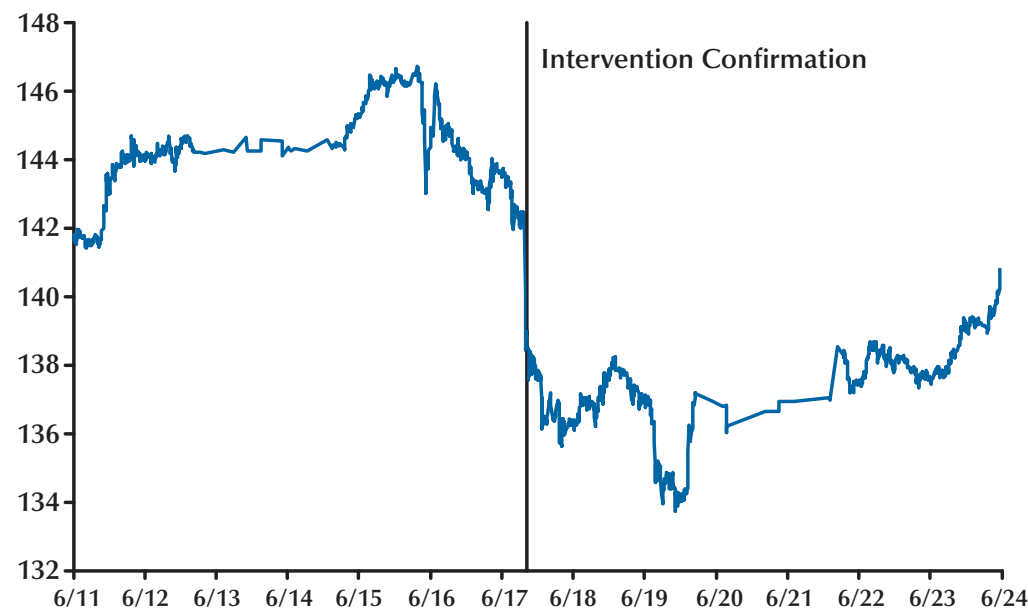

NOTE: Panel A shows the daily annualized realized volatility, computed from 5-minute squared returns, for the JPY/USD market from June 11, 1998, to June 23, 1998. The horizontal lines show the 10th and 90th percentiles of volatility for the JPY/USD over the March 26, 1998-March 31, 2011 period. Panel B shows the evolution of the JPY/USD price over the same dates. In both cases, the vertical line denotes the date/time of coordinated foreign exchange intervention. 
Figure 11

USD/EUR Market Behavior Near the September 22, 2000, Intervention

A.

Realized 5-Minute Volatility (annualized)

USD/EUR

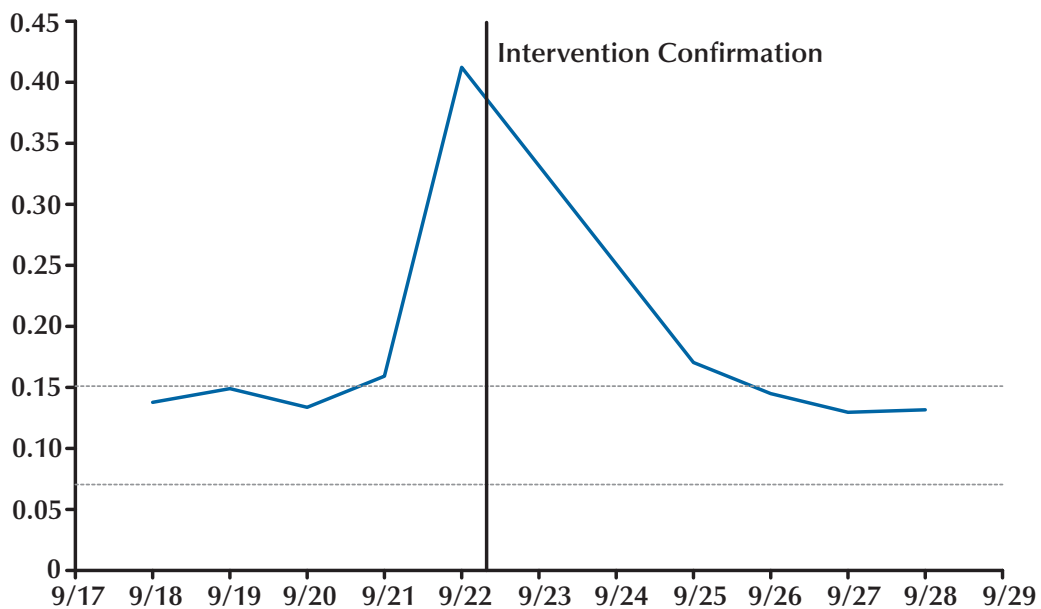

B.

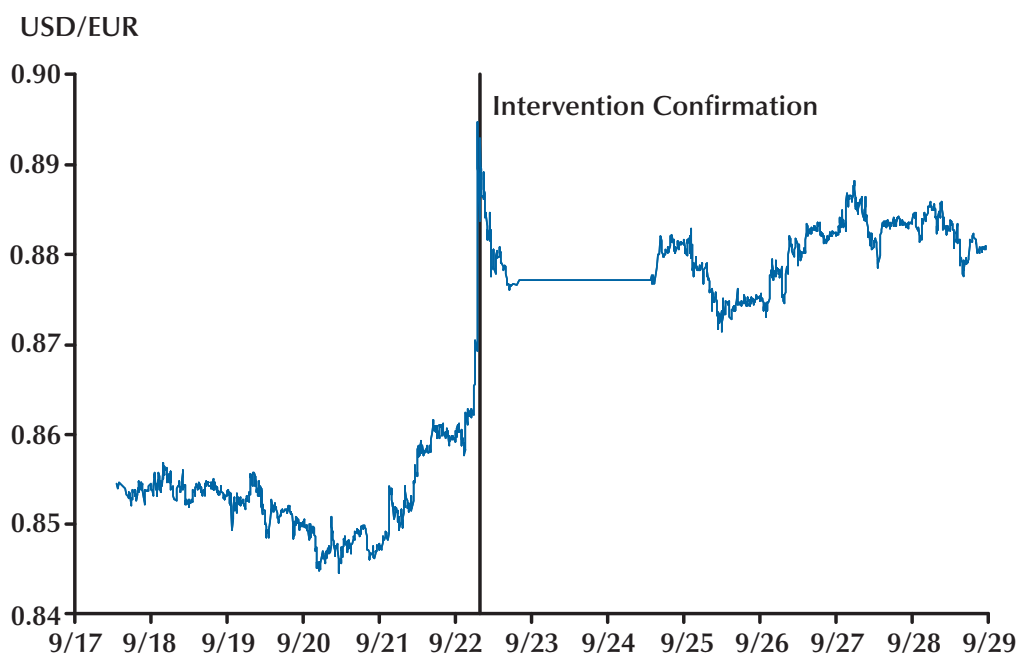

NOTE: Panel A shows the daily annualized realized volatility, computed from 5-minute squared returns, for the USD/EUR market from September 18, 2000, to September 28, 2000. The horizontal lines show the 10th and 90th percentiles of volatility for the USD/EUR market over the April 20, 1998-March 31, 2011 period. Panel B shows the evolution of the USD/EUR price over the same dates. In both cases, the vertical line denotes the time of coordinated foreign exchange intervention. 
is a 12 percent chance that the JPY/USD rate will decline below its pre-intervention value and, within 6 months, there is a 32 percent chance that it will do so. ${ }^{21}$ Regardless of the size of the intervention effect, the uncertainty about its effect must grow with the forecast horizon, so it can never be proved that intervention has a permanent effect.

It is also important to note that an intervention's effect need not be permanent for it to be helpful. That is, if intervention stabilizes markets by correcting misalignments or simply reintroduces a two-sided market that prevents a drastic overshoot of exchange rates, then a "permanent" intervention effect would neither be needed nor desired. Rather, the desired effect of the intervention would simply be to hasten the return to longrun equilibrium or prevent further misalignment. In either case, the long-run value of the exchange rate would be unchanged, although the intervention achieved its goal.

\section{CONCLUSION}

This article has detailed the circumstances of the March 18, 2011, intervention to weaken the Japanese yen, put current implicit intervention policy in the context of historical intervention practice, and compared the March 2011 effects with those of the two other most recent U.S. interventions: the June 1998 effort to strengthen the JPY and the September 2000 collaboration to strengthen the EUR.

After the disastrous March 11 earthquake in Japan, the yen appreciated strongly against other major currencies. The financial press cited expectations of foreign capital repatriation as the driv-

\footnotetext{
${ }^{21}$ If the annual SD of returns is 12 percent, then the annual variance of returns is $0.12^{2}=0.0144$. If returns are uncorrelated, then the 1-month and 6-month SDs of returns are

$\sqrt{0.0144 / 12} \approx 0.035$ and $\sqrt{0.0144 / 2} \approx 0.085$,

respectively. The probabilities that the exchange rate will decline by more than 4 percent over 1 and 6 months are the values of the cumulative standard normal distribution function at $-0.04 / 0.035$ and $-0.04 / 0.085$, which are approximately 12 percent and 32 percent, respectively. In fact, the distribution of exchange rate returns has considerably fatter tails than a normal distribution, so this calculation surely understates the likelihood that the intervention will seem ineffective.
}

ing force behind this appreciation, which rapidly drove the yen's value above historically implied levels and increased volatility substantially, which made markets "disorderly." The G-7 finance ministers announced on the evening of March 17 that they would intervene the next day to assist Japanese authorities in stemming the yen's rise. The immediate result was a 4 percent decline in the yen's value and a large reduction in foreign exchange market volatility over the next two days. In addition, the Nikkei 225 index gained ground and its volatility returned to normal.

In several ways, the circumstances leading up to the March 18 intervention and the immediate results were similar to those of the June 1998 and September 2000 coordinated interventions. In each case, special circumstances-an earthquake, a recent financial crisis, or a new central bank and incipient recession-made exchange rate misalignments more costly than usual. Financial markets became disorderly (one-sided) as volatility increased. Press reports of intervention discussions might have caused modest exchange rate movements before the actual intervention (or announcement). Exchange rates reacted strongly and quickly to each intervention (or announcement), moving about 4 percent in the desired direction and with volatility declining substantially.

Since 1995 most advanced governments/ central banks have used intervention only very sparingly as a policy tool. Examination of coordinated interventions during this period shows that intervention is not a magic wand that authorities can use to move exchange rates at will. It can be a very effective tool in certain circumstances, however, to coordinate market expectations about fundamental values of the exchange rate and calm disorderly foreign exchange markets by reintroducing two-sided risk. This article has shown that intervention remains a very effective tool, even as its use has become less common. 


\section{Neely}

\section{REFERENCES}

Almekinders, Geert J. and Eijffinger, Sylvester C.W. "A Friction Model of Daily Bundesbank and Federal Reserve Intervention.” Journal of Banking and Finance, September 1996, 20(8), pp. 1365-80.

Andersen, Torben G. and Bollerslev, Tim. "Deutsche Mark-Dollar Volatility: Intraday Activity Patterns, Macroeconomic Announcements, and Longer Run Dependencies.” Journal of Finance, February 1998, 53(1), pp. 219-65.

Beine, Michel; Lahaye, Jérôme; Laurent, Sébastien; Neely, Christopher J. and Palm, Franz C. "Central Bank Intervention and Exchange Rate Volatility, Its Continuous and Jump Components." International Journal of Finance and Economics, April 2007, 12(2), pp. 201-23.

Bordo, Michael D.; Humpage, Owen and Schwartz, Anna J. "The Historical Origins of U.S. Exchange Market Intervention Policy.” International Journal of Finance and Economics, April 2007, 12(2), pp. 109-32.

Bordo, Michael D.; Humpage, Owen F. and Schwartz, Anna J. "U.S. Intervention and the Early Dollar Float: 1973-1981.” Working Paper No. 10-23, Federal Reserve Bank of Cleveland, December 2010; www.clevelandfed.org/research/workpaper/2010/wp1023.pdf.

Campa, José Manuel and Chang, P.H. Kevin. "The Forecasting Ability of Correlations Implied in Foreign Exchange Options.” Journal of International Money and Finance, December 1998, 17(6), pp. 855-80.

Department of Finance Canada. “Official International Reserves, 2011-033.” April 2011; www.fin.gc.ca/n11/11-033-eng.asp.

Dominguez, Kathryn M. "Market Responses to Coordinated Central Bank Intervention.” Carnegie-Rochester Conference Series on Public Policy, January 1990, 32(1), pp. 121-63.

Dominguez, Kathryn. “The Market Microstructure of Central Bank Intervention.” Journal of International Economics, January 2003, 59(1), pp. 25-45.

Dow Jones Online News. “Yen Intervention Reportedly ‘Hotly Debated’ by Fed, Treasury.” June 18, 1998.

Edison, Hali J. "The Effectiveness of Central Bank Intervention: A Survey of the Literature after 1982." Special Papers in International Economics No. 18, Princeton University Department of Economics, July 1993; www.princeton.edu/ ies/IES Special Papers/SP18.pdf.

European Central Bank Press Release. "Consolidated Financial Statement of the Eurosystem as at 25 March 2011." March 2011; www.ecb.europa.eu/press/pr/wfs/2011/html/fs110329.en.html.

Fama, Eugene F. "Efficient Capital Markets: A Review of Theory and Empirical Work.” Journal of Finance, May 1970, 25(2), pp. 383-417.

Fatum, Rasmus and Hutchison, Michael. "Is Intervention a Signal of Future Monetary Policy? Evidence from the Federal Funds Futures Market.” Journal of Money, Credit, and Banking, February 1999, 31(1), pp. 54-69.

Federal Open Market Committee. "Transcript of Federal Open Market Committee Meeting of May 16, 1989.” 1989a; www.federalreserve.gov/monetarypolicy/files/FOMC19890516meeting.pdf. 
Federal Open Market Committee. "Transcript of Federal Open Market Committee Meeting of August 22, 1989.” 1989b; www.federalreserve.gov/monetarypolicy/files/FOMC19890822meeting.pdf.

Fischer, Andreas M. and Zurlinden, Mathias. "Exchange Rate Effects of Central Bank Interventions: An Analysis of Transaction Prices.” Economic Journal, October 1999, 109(458), pp. 662-76.

Group of Seven (G-7). “G-7 Statement on Currencies.” March 18, 2011; www.smh.com.au/business/markets/g7-statement-on-currencies-20110318-1bzsj.html.

Hewett, Jennifer. "How America Saved the Yen, for Now.” The Age, June 20, 1998.

HM Treasury. "U.K. Official Holdings of International Reserves March 2011.” National Statistics, April 5, 2011; www.hm-treasury.gov.uk/d/pn 37 11.pdf.

Holland, Tom. "Euro Intervention Good for Asia, Wall St.” Far Eastern Economic Review, September 28, 2000.

Hosaka, Tomoko A. “Japan Disaster Likely to Be World’s Costliest.” Associated Press, March 23, 2011; http://finance.yahoo.com/news/Japan-disaster-likely-to-be-apf-2425809672.html?x=0.

International Monetary Fund. IMF Annual Report 1981. Washington, DC: IMF Publication Services, 1981.

Jensen, Michael C. "Some Anomalous Evidence Regarding Market Efficiency.” Journal of Financial Economics, June-September 1978, 6(2-3), pp. 95-101.

Kaminsky, Graciela L. and Lewis, Karen K. "Does Foreign Exchange Intervention Signal Future Monetary Policy?" Journal of Monetary Economics, April 1996, 37(2-3), pp. 285-312.

Kearns, Jonathan and Rigobon, Roberto. "Identifying the Efficacy of Central Bank Interventions: Evidence from Australia and Japan.” Journal of International Economics, May 2005, 66(1), pp. 31-48.

Klein, Michael W. and Lewis, Karen K. “Learning about Intervention Target Zones.” Journal of International Economics, November 1993, 35(3-4), pp. 275-95.

Lewis, Karen K. "Can Learning Affect Exchange-Rate Behavior? The Case of the Dollar in the Early 1980s." Journal of Monetary Economics, January 1989, 23(1), pp. 79-100.

Lewis, Karen K. "Are Foreign Exchange Intervention and Monetary Policy Related and Does It Really Matter?" Journal of Business, April 1995, 68(2), pp. 185-214.

McCormick, Liz. “U.S. Bought \$1 Billion During March Yen Intervention, Federal Reserve Says.” Bloomberg, May 13, 2011; www.bloomberg.com/news/2011-05-13/fed-bought-1-billion-of-u-s-currency-during-marchg-7-yen-intervention.html.

Ministry of Finance Japan. "Foreign Exchange Intervention Operations (January-March 2011).” May 11, 2011; www.mof.go.jp/english/international policy/reference/feio/quarter/e2301 03.htm.

National Police Agency of Japan. "Damage Situation and Police Countermeasures Associated with 2011 Tohoku District—off the Pacific Ocean Earthquake.” May 2011; www.npa.go.jp/archive/keibi/biki/higaijokyo e.pdf.

Neely, Christopher J. “An Analysis of Recent Studies of the Effect of Foreign Exchange Intervention.” Federal Reserve Bank of St. Louis Review, November/December 2005, 87(6), pp. 685-717; http://research.stlouisfed.org/publications/review/05/11/Neely.pdf. 


\section{Neely}

Neely, Christopher J. "Identifying the Effects of U.S. Intervention on the Levels of Exchange Rates." Working Paper No. 2005-031C, Federal Reserve Bank of St. Louis, May 2005, revised May 2006; http://research.stlouisfed.org/wp/2005/2005-031.pdf.

Neely, Christopher J. “Central Bank Authorities' Beliefs about Foreign Exchange Intervention.” Journal of International Money and Finance, February 2008, 27(1), pp. 1-25.

Payne, Richard and Vitale, Paolo. "A Transaction Level Study of the Effects of Central Bank Intervention on Exchange Rates.” Journal of International Economics, December 2003, 61(2), pp. 331-52.

Pett, David. “G-7 to Help Drive Down Rising Yen.” Financial Post, March 17, 2011.

Reitz, Stefan and Taylor, Mark P. "The Coordination Channel of Foreign Exchange Intervention: A Nonlinear Microstructural Analysis.” European Economic Review, January 2008, 52(1), pp. 55-76.

Reserve Bank of Australia. "The Exchange Rate and the Reserve Bank's Role in the Foreign Exchange Market." www.rba.gov.au/mkt-operations/foreign-exchg-mkt.html.

Sack, Brian and McNeil, Kevin. "Treasury and Federal Reserve Foreign Exchange Operations, January-March 2011.” Federal Reserve Bank of New York Quarterly Report, April 2011; www.newyorkfed.org/newsevents/news/markets/2011/fxq111.pdf.

Sarno, Lucio and Taylor, Mark P. "Official Intervention in the Foreign Exchange Market: Is It Effective and, If So, How Does It Work?” Journal of Economic Literature, September 2001, 39(3), pp. 839-68.

Shilling, A. Gary. "Scoreboard: A Frank Self-Appraisal of Where I Went Wrong and Where I Went Right in the Year Just Past." Forbes, February 15, 1993, 151(4), p. 236.

Shleifer, Andrei and Vishny, Robert W. "The Limits of Arbitrage." Journal of Finance, March 1997, 52(1), pp. 35-55.

Taylor, Mark P. "Official Foreign Exchange Intervention as a Coordinating Signal in the Dollar-Yen Market.” Pacific Economic Review, February 2005, 10(1), pp. 73-82.

Truman, Edwin M. "The Limits of Exchange Market Intervention,” in C. Fred Bergsten and John Williamson, eds., Dollar Overvaluation and the World Economy (Special Report 16). Washington, DC: Institute for International Economics, 2003; pp. 247-65.

Vieira, Paul. "G-7 Scrambles to Calm Markets in Yen Mayhem.” Financial Post, March 17, 2011a.

Vieira, Paul. "Japan Does Heavylifting to Devalue Soaring Yen: G-7 Help 'Symbolic'; Currency Falls by the Most in More than Two Years." Financial Post, March 19, 2011b. 